\title{
Diseases and symptoms associated with changes in postural balance in diabetics: an integrating literature review
}

\author{
Eliza Mikaele Tavares da Silva ${ }^{1}$ \\ https://orcid.org/0000-0002-9277-4657 \\ Bartolomeu Fagundes de Lima Filho ${ }^{1}$ \\ https://orcid.org/0000-0002-3326-389X \\ Érika Barioni Mantello ${ }^{1}$ \\ https://orcid.org/0000-0003-3200-5474 \\ André Gustavo Pires de Sousa ${ }^{1}$ \\ https://orcid.org/0000-0001-8426-2320 \\ José Diniz Júnior ${ }^{1}$ \\ https://orcid.org/0000-0002-2327-945X \\ Juliana Maria Gazzola ${ }^{1}$ \\ https://orcid.org/0000-0002-9333-1831
}

Universidade Federal do Rio Grande do Norte - UFRN, Natal, Rio Grande do Norte, Brasil.

Research conducted at the Department of Speech-Language Pathology and Audiology, Federal University of Rio Grande do Norte - UFRN, Natal, Rio Grande do Norte, Brazil.

Conflict of interests: Nonexistent

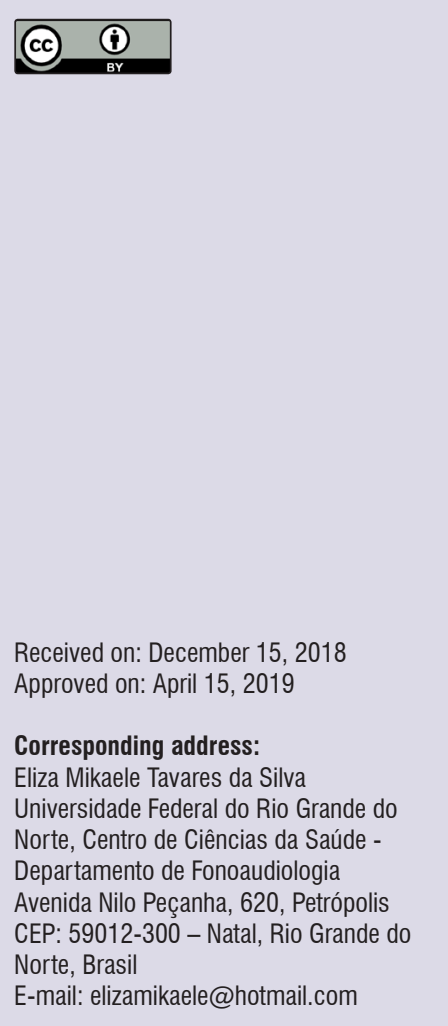

\section{ABSTRACT}

Purpose: to verify the diseases and symptoms associated with changes in postural balance in middle-aged and elderly individuals with type 2 diabetes mellitus.

Methods: an integrative review was performed using the following descriptors: "Dizziness," "Vertigo," "Vestibular Diseases," "Labyrinth Diseases," and "Type 2, Diabetes Mellitus" in English and in Portuguese in databases such as PubMed, SciELO, LILACS, Web of Science, and Scopus. Observational articles involving individuals aged 40 years or more with type 2 diabetes mellitus and with alteration in postural balance having presented at least one disease or symptom associated with that alteration were selected.

Results: the search yielded 1,209 articles, but only five met the eligibility criteria. Individuals in the selected studies had systemic arterial hypertension, high body mass index, peripheral neuropathy, and postural instability when walking on irregular surfaces and in the dark, when looking at moving objects, moving the head quickly and changing posture, resulting in stumbling when walking, and falls. The articles were classified as IIb and III, according to the levels of evidence of the American SpeechLanguage Hearing Association.

Conclusion: the subjects in the studied articles presented cardiovascular alterations, peripheral neuropathy, vestibular symptoms, difficulties in tasks/movements in challenging contexts, and falls.

Keywords: Dizziness; Vertigo; Diabetes Mellitus, Type 2 


\section{INTRODUCTION}

Brazil has the fourth highest number of diabetic people in the world ${ }^{1,2}$. In 2015, there were around 14.3 million cases among adults and the elderly, and 23.3 million cases are projected by $2050^{1-3}$.

Several factors are considered responsible for the increased incidence and prevalence of diabetes mellitus (DM) in Brazil and worldwide ${ }^{3,4}$. These include lifestyle modification characterized by unbalanced eating patterns, obesity, sedentary lifestyle, and aging $^{3-5}$.

Among DM types, type 2 DM (DM2) has been more prevalent in Brazil and in the world in recent decades as it is considered a global epidemic, accounting for about $90 \%$ of all cases of diabetes ${ }^{1,3}$.

The presented context raises concerns as it is associated with an exorbitant cost for the society and government. It is estimated that $15.3 \%$ of hospital costs of the Unified Health System in Brazil, between 2008 and 2010 , were caused by DM. Financial damages are not the only concerns as DM2 can cause damage to the organs and systems of the body, reducing functional capacity and autonomy $y^{1,6}$.

DM2 is considered a potential cause of changes in postural balance $(\mathrm{PB})^{7}$. Patients with diabetes often present with disorders in the sensory systems responsible for the maintenance of PB due to comorbidities such as retinopathy, peripheral neuropathy, and disorders in the vestibular system ${ }^{7-10}$.

Although the diabetic population is increasing ${ }^{1,3}$ and the relationship between DM and PB changes is $\mathrm{known}^{7,11}$, few studies have provided information on the diseases and/or symptoms associated with this change in the diabetic population; therefore, these factors are poorly known clinically, which results in difficulties in performing a comprehensive evaluation and in adequate management of patients ${ }^{3,5}$.

The recognition of the factors (diseases and/ or symptoms) associated with changes in $\mathrm{PB}$ in the diabetic population is extremely important, as this will represent an important contribution from the perspective of an adequate evaluation and rehabilitation process. Furthermore, it will enable the construction of preventive strategies and guide the appropriate management (referrals, therapeutic planning, and choice of treatment) of patients, as some comorbidities may cause and/or intensify PB changes.

The present review aims to verify the diseases and symptoms associated with PB changes in middle-aged and elderly individuals presented with DM2.

\section{METHODS}

An integrative review was performed from May to November 2018, using the databases PubMed (National Library of Medicine National Institutes of Health), SciELO (Scientific Electronic Library Online), LILACS (Latin-American and Caribbean Health Sciences), Web of Science, and Scopus.

The guiding question of the research was as follows: "What diseases and symptoms are associated with PB changes in patients with DM2?" It should be emphasized that the age of the individuals in the study was based on the range provided in the guidelines of the Brazilian Society of Diabetes, which states that the diagnosis of DM2 typically occurs after 40 years of age $^{12}$.

The search was performed using the descriptors (in Portuguese and English) of "Dizziness," "Vertigo," "Vestibular Diseases," "Labyrinth Diseases," and "Type 2, Diabetes Mellitus" in the following combinations: "Diabetes Mellitus Type 2 and Dizziness"; "Type 2, Diabetes Mellitus and Vertigo"; "Type 2, Diabetes Mellitus and Vestibular Diseases"; "Type 2, Diabetes Mellitus and Labyrinth Diseases"; "Type 2, Diabetes Mellitus and Dizziness"; "Type 2, Diabetes Mellitus and Vertigo"; "Type 2, Diabetes Mellitus and Doenças Vestibulares"; and "Type 2, Diabetes Mellitus and Doenças do Labirinto".

Articles in the present study were selected only if they met the following eligibility criteria: the studies had to be (a) observational; (b) published in the period from 2008 to 2018; (c) subjects with DM2, aged 40 years or over, with alteration in PB; and (d) who presented at least one disease or symptom associated with PB changes, by means of inferential or descriptive analysis. We excluded articles that (a) presented an inclusion criterion to have certain associated disease(s) not secondary to DM2 because this study aimed to focus on one health condition in a particular population and not in the population in general, (b) presented individuals with postural hypotension $(\mathrm{PH})$ as this may be asymptomatic and their varied changes may or may not cause changes in $\mathrm{PB}^{13}$, and (c) were repeated in the databases. Notably, prospective studies have analyzed the initial symptoms of the treatment, as these can be minimized or remedied with the same.

With respect to the errors and biases that may be present in this type of research, we highlight the random error involving the sample and its real population values, which can be reduced by opting for articles with a larger sample. Systematic or methodological 
error was minimized in this research by revising the methodology and on the basis of review studies already published in journals of high impact. Selection, information, and confounding biases, were minimized by a detailed analysis of the eligibility criteria, a critical review of the methodology, and by the peer review of the manuscript ${ }^{14}$.

The selected articles were researched independently and selected by two trained evaluators involved with the manuscript production to minimize citation loss. In the case of divergence, a third evaluator was requested for a tie-breaker criterion.

The selection took place in three stages: by reading (a) the titles, (b) the summaries of articles, and (c) the article in its entirety.

The articles were analyzed and classified according to the levels of evidence used by American SpeechLanguage Hearing Association (ASHA) in 2004 ${ }^{15}$, adapted from the Scottish Intercollegiate Guideline. These are classified as follows: la, well-designed meta-analysis of multiple controlled and randomized studies; Ib, randomized and well-designed controlled study; Ila, well-designed non-randomized controlled study; Ilb, well-designed almost experimental study; III, well-designed non-experimental study; and IV, expert committee report, consensus conference, clinical expertise experience.

\section{LITERATURE REVIEW}

The initial search yielded 1209 identified articles, 1204 of these were excluded (927, based on the titles; 257, duplication between descriptor combinations or databases; 3 , during the reading of the abstract because they did not contemplate the topic addressed; and 17 , during the reading the full text as they did not meet the eligibility criteria). Thus, 5 articles met the eligibility criteria of this research; these articles were selected and reviewed.

Table 1 describes the characteristics of the studies incorporated in this review, such as author/year/ country, objective, cases, type of study, used tools, main findings, diseases and/or symptoms found in individuals with $\mathrm{DM} 2$, alteration of $\mathrm{PB}$, and level of evidence.

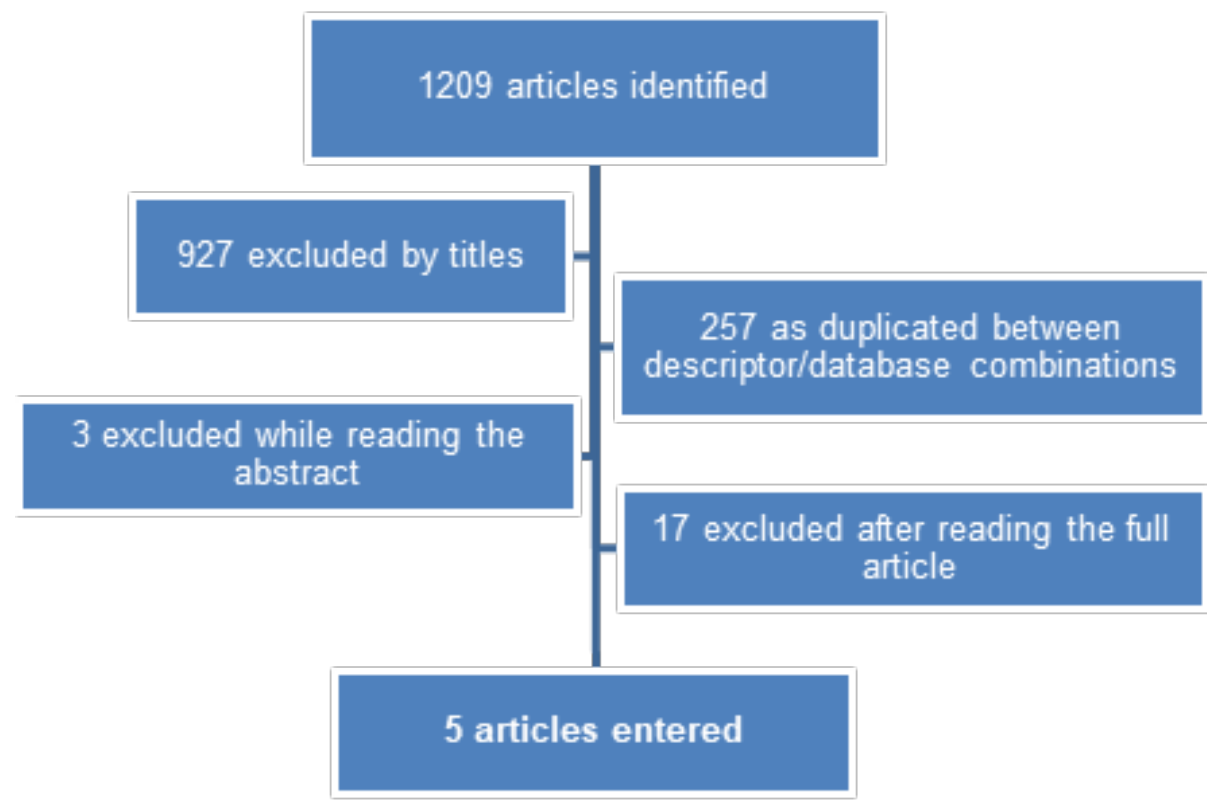

Figure 1. Article selection flow 
Table 1. Characteristics of the studies inserted

\begin{tabular}{|c|c|c|c|c|c|c|c|}
\hline $\begin{array}{l}\text { Author/year/ } \\
\text { country }\end{array}$ & Objective & Cases & $\begin{array}{l}\text { Type of } \\
\text { study }\end{array}$ & Tools used & Main findings & $\begin{array}{c}\text { Diseases and/or Symptoms } \\
\text { found in individuals with } \\
\text { DM2 and altered body } \\
\text { balance. }\end{array}$ & $\begin{array}{c}\text { Evidence } \\
\text { Level } \\
\text { (ASHA) }\end{array}$ \\
\hline $\begin{array}{l}\text { Aranda, Meza, } \\
\text { Rodríguez, } \\
\text { Mantilla, } \\
\text { Jáuregui-Renaud } \\
(2009)^{16} \\
\text { Mexico }\end{array}$ & $\begin{array}{l}\text { To assess the } \\
\text { influence of } \\
\text { diabetic peripheral } \\
\text { neuropathy on self- } \\
\text { reported disability } \\
\text { and postural control } \\
\text { of patients with } \\
\text { peripheral vestibular } \\
\text { disease before and } \\
\text { after a standardized } \\
\text { program of } \\
\text { vestibular } \\
\text { rehabilitation } \\
\text { (Cawthorne \& } \\
\text { Cooksey exercises). }\end{array}$ & $\begin{array}{l}-10 \text { subjects with } \\
\text { DM2 and without } \\
\text { neuropathy with } \\
\text { mean age } 54,9 \\
\text { years of age; } \\
-10 \text { subjects with } \\
\text { DM2 and with } \\
\text { neuropathy and } \\
\text { mean age of } 57,2 \text {. }\end{array}$ & $\begin{array}{l}\text { Prospective } \\
\text { study }\end{array}$ & $\begin{array}{l}\text { - Standardized } \\
\text { questionnaire } \\
\text { related to body } \\
\text { balance; } \\
\text {-Dizziness } \\
\text { Handicap Inventory; } \\
\text {-Posturography; } \\
\text { - Cawthorne } \\
\text { \& Cooksey } \\
\text { Rehabilitation } \\
\text { Program }\end{array}$ & $\begin{array}{l}\text { Peripheral } \\
\text { neuropathy } \\
\text { contributes to } \\
\text { self-reported } \\
\text { disability and may } \\
\text { interfere with the } \\
\text { rehabilitation of } \\
\text { body balance. }\end{array}$ & $\begin{array}{l}\text { Patients with DM2 presented } \\
\text { with systemic arterial } \\
\text { hypertension, dizziness, } \\
\text { vertigo, postural instability } \\
\text { when looking at moving } \\
\text { objects, walking on uneven } \\
\text { surfaces, walking in the dark, } \\
\text { moving the head quickly } \\
\text { and changing posture. } \\
\text { Individuals with NP presented } \\
\text { a higher frequency of all the } \\
\text { symptoms mentioned above, } \\
\text { except for postural instability } \\
\text { when looking at moving } \\
\text { objects. }\end{array}$ & Ilb \\
\hline $\begin{array}{l}\text { D'Silva et al } \\
\qquad(2017)^{17} \\
\text { The United States } \\
\text { of America }\end{array}$ & $\begin{array}{l}\text { To analyze } \\
\text { otolytic function } \\
\text { using vestibular } \\
\text { myogenic evoked } \\
\text { potential (VEMP) } \\
\text { in people with } \\
\text { DM and VPPBB } \\
\text { and to examine } \\
\text { the relationships } \\
\text { between VEMP and } \\
\text { variables related to } \\
\text { diabetes. }\end{array}$ & $\begin{array}{l}\text { - Participants } \\
\text { between the ages of } \\
40 \text { and } 65 \\
-20 \text { controls; } \\
-19 \text { individuals with } \\
\text { type } 2 \text { diabetes } \\
\text { without vestibular } \\
\text { alterations } \\
-18 \text { individuals with } \\
\text { unilateral posterior } \\
\text { canal VPPB without } \\
\text { DM } \\
-14 \text { individuals with } \\
\text { unilateral posterior } \\
\text { canal VPPB and DM }\end{array}$ & $\begin{array}{l}\text { Transversal } \\
\text { study }\end{array}$ & $\begin{array}{l}\text { - Self-reporting } \\
\text { of clinical data, } \\
\text { confirmed by } \\
\text { electronic medical } \\
\text { records; } \\
\text { - Michigan } \\
\text { Neuropathy } \\
\text { Screening } \\
\text { Instrument; } \\
\text { - VPPB cervical; } \\
\text { - VPPB ocular. }\end{array}$ & $\begin{array}{l}\text { VPPB and DM2 } \\
\text { may independently } \\
\text { affect utricular and } \\
\text { saccule function, } \\
\text { however, do not } \\
\text { appear to have } \\
\text { cumulative effect. }\end{array}$ & $\begin{array}{l}\text { Systemic arterial } \\
\text { hypertension, peripheral } \\
\text { neuropathy, and high BMI. }\end{array}$ & III \\
\hline $\begin{array}{l}\text { D'Silva, Whitney, } \\
\text { Santos, Dai, } \\
\text { Kluding (2017) } \\
\text { The United States } \\
\text { of America }\end{array}$ & $\begin{array}{l}\text { To compare } \\
\text { the severity } \\
\text { of symptoms, } \\
\text { mobility, and body } \\
\text { balance before and } \\
\text { after the otolytic } \\
\text { repositioning } \\
\text { maneuver (ORM) } \\
\text { in people with } \\
\text { posterior canal VPP, } \\
\text { with and without } \\
\text { DM. }\end{array}$ & $\begin{array}{l}\text { - Participants aged } \\
40 \text { to } 80 \text { years } \\
-34 \text { individuals with } \\
\text { VPPB } \\
-16 \text { individuals with } \\
\text { VPPB + DM2 }\end{array}$ & $\begin{array}{l}\text { Prospective } \\
\text { study }\end{array}$ & $\begin{array}{l}\text {-Dix-Hallpike; } \\
\text {-Dizziness } \\
\text { Handicap Inventory; } \\
\text {-Functional gait } \\
\text { assessment; } \\
\text { - Postural } \\
\text { oscillation } \\
\text { variables; } \\
\text {-Michigan } \\
\text { Neuropathy } \\
\text { Screening } \\
\text { Instrument; } \\
\text { Self-reporting } \\
\text { of clinical data, } \\
\text { confirmed by } \\
\text { electronic medical } \\
\text { records; } \\
\text {-Verification } \\
\text { of glycated } \\
\text { hemoglobin. }\end{array}$ & $\begin{array}{l}\text { There were } \\
\text { no differences } \\
\text { in severity of } \\
\text { symptoms, mobility } \\
\text { deficits or efficacy } \\
\text { of ORM treatments } \\
\text { in people with } \\
\text { posterior canal } \\
\text { VPPB with and } \\
\text { without DM. }\end{array}$ & $\begin{array}{l}\text { High body mass index, } \\
\text { peripheral neuropathy. }\end{array}$ & $\mathrm{llb}$ \\
\hline
\end{tabular}




\begin{tabular}{|c|c|c|c|c|c|c|c|}
\hline $\begin{array}{l}\text { Author/year/ } \\
\text { country }\end{array}$ & Objective & Cases & $\begin{array}{l}\text { Type of } \\
\text { study }\end{array}$ & Tools used & Main findings & $\begin{array}{l}\text { Diseases and/or Symptoms } \\
\text { found in individuals with } \\
\text { DM2 and altered body } \\
\text { balance. }\end{array}$ & $\begin{array}{l}\text { Evidence } \\
\text { Level } \\
\text { (ASHA) }\end{array}$ \\
\hline $\begin{array}{l}\text { Jáuregui-Renaud, } \\
\text { Sánchez, Olmos, } \\
\text { González-Barcena } \\
(2009)^{19} \\
\text { Mexico }\end{array}$ & $\begin{array}{l}\text { To evaluate the } \\
\text { prevalence of body } \\
\text { balance symptoms } \\
\text { in type } 2 \text { diabetes } \\
\text { mellitus (DM2) in } \\
\text { the first level of } \\
\text { health care. }\end{array}$ & $\begin{array}{l}-101 \text { patients with } \\
\text { DM2 and mean age } \\
\text { of } 54,3 \text { years } \\
-101 \text { patients } \\
\text { without DM2 and } \\
\text { mean age of } 53,8 \\
\text { years }\end{array}$ & $\begin{array}{l}\text { Transversal } \\
\text { study }\end{array}$ & $\begin{array}{l}\text { - Standardized } \\
\text { questionnaire } \\
\text { related to body } \\
\text { balance. }\end{array}$ & $\begin{array}{l}\text { Patients with DM2 } \\
\text { showed a higher } \\
\text { frequency of all } \\
\text { the investigated } \\
\text { symptoms. The } \\
\text { most frequent } \\
\text { symptoms were } \\
\text { dizziness (49\%), } \\
\text { postural instability } \\
\text { when changing } \\
\text { position (43\%) and } \\
\text { postural instability } \\
\text { when walking on } \\
\text { uneven surfaces } \\
\text { (38\%). }\end{array}$ & $\begin{array}{l}\text { Dizziness, vertigo, postural } \\
\text { instability when changing } \\
\text { positions, moving the head, } \\
\text { walking on uneven surfaces } \\
\text { and in the dark and looking } \\
\text { at moving objects; more than } \\
\text { three unexplained falls during } \\
\text { the year, stumbling when } \\
\text { walking. }\end{array}$ & III \\
\hline $\begin{array}{l}\text { D'Silva et al } \\
(2017)^{20} \\
\text { The United States } \\
\text { of America }\end{array}$ & $\begin{array}{l}\text { Examine the } \\
\text { postural oscillation } \\
\text { in } \\
\text { people with type } \\
2 \text { diabetes who } \\
\text { have symptomatic, } \\
\text { untreated VPPB. }\end{array}$ & $\begin{array}{l}\text { Participants aged } \\
40-65 \text { years } \\
-14 \text { controls } \\
-14 \text { diabetic } \\
\text { individuals } \\
-13 \text { individuals with } \\
\text { VPPB } \\
-11 \text { individuals with } \\
\text { VPPB and DM2 }\end{array}$ & $\begin{array}{l}\text { Transversal } \\
\text { study }\end{array}$ & $\begin{array}{l}\text { - Condition 1: } \\
\text { Standing on a firm } \\
\text { surface with feet } \\
\text { together, eyes open. } \\
\text {-Condition 2: } \\
\text { Standing on a firm } \\
\text { surface with feet } \\
\text { together, eyes } \\
\text { closed. } \\
\text {-Condition 3: } \\
\text { standing on a foam } \\
\text { cushion with feet } \\
\text { together and eyes } \\
\text { open. } \\
\text {-Condition 4: } \\
\text { Standing on a } \\
\text { foam cushion with } \\
\text { feet together, eyes } \\
\text { closed. } \\
\text {-Condition } 5 \text { : in the } \\
\text { tandem position } \\
\text { with eyes open on a } \\
\text { firm surface. }\end{array}$ & $\begin{array}{l}\text { The presence of } \\
\text { diabetic peripheral } \\
\text { neuropathy may } \\
\text { reduce } \\
\text { postural stability. } \\
\text { In individuals with } \\
\text { VPPB, diabetes } \\
\text { and peripheral } \\
\text { neuropathy, the } \\
\text { tandem position } \\
\text { may be an easy } \\
\text { test to perform in } \\
\text { the clinical setting } \\
\text { to detect postural } \\
\text { instability. }\end{array}$ & High body mass index. & III \\
\hline
\end{tabular}

Subtitle: DM2, Diabetes mellitus type 2; VPPB, Benign paroxysmal positional vertigo; ORM, Otolytic repositioning maneuver; VEMP, Vestibular myogenic-evoked potential

Among the five articles reviewed in this study, two ${ }^{16,17}$ cited the systemic arterial hypertension (SAH) variable and, in both, diabetic individuals with PB alteration had a higher frequency of this disease. SAH causes an increase in blood pressure levels that leads to functional and/or structural alterations in some organs and may lead to impairment of capillary blood flow and oxygen transport ${ }^{21,22}$. Thus, nutrients are not adequately supplied to the organs, such as the inner ear ${ }^{7,21,22}$.

The inner ear has intense metabolic activity, but unlike other organs, it does not have a stored energy reserve, making it more sensitive to fluctuations due to the requirement of resources, specifically glucose and oxygen, necessary for its adequate functioning ${ }^{6,7}$. Thus, hypertension and DM2 are factors that can cause changes in $\mathrm{PB}^{21}$. However, it remains unclear whether the overlap of the two diseases may increase the risk of bodily imbalance. Increase in this risk may be a side effect of uncontrolled SAH and the only symptom of hypertensive crisis, that is, an alert signal for circulatory changes $^{23}$.

High body mass index (BMI) was described in three articles ${ }^{17,18,20}$, showing a population with high a BMI average, above $30 \mathrm{Kg} / \mathrm{m}^{2}$, in relation to the other groups. According to the World Health Organization, a BMI equal to or above $30 \mathrm{Kg} / \mathrm{m}^{2}$ is characterized as obese $^{24}$.

The selected articles did not explain the relationship of high BMI (obesity) with changes in PB. However, literature describes the association of obesity with DM2 due to the increased release of substances such as fatty acids not esterified by adipose tissue, which 
induce insulin resistance, impairing the function of insulin-producing $\beta$ cells, and, consequently, generating failures in glycemic control ${ }^{23,25}$. Currently, obesity is associated with an increased risk of falls, functional disabilities ${ }^{26}$, and depressive symptoms ${ }^{27}$.

D'Silva et al. (2017) ${ }^{17}$ and D'Silva et al. (2017) ${ }^{18}$ reported differences between individuals with DM2, with and without PB changes in relation to peripheral neuropathy (PN). PN is one of the main complications of DM, affecting between $5 \%$ and $80 \%$ of this population. This comorbidity may interrupt the afferences and efferences of the extremities of the lower limbs. Thus, proprioception becomes deficient, and consequently, the maintenance of the posture, reactive strategy of the step, and execution of the steps become more difficult, leaving the individuals more susceptible to falls ${ }^{10,12,26}$.

The data presented corroborates Aranda's et al. $(2009)^{16}$ article, which shows the comparison of the symptoms related to $\mathrm{PB}$ in diabetics with peripheral vestibular disease, with and without PN. Higher frequencies of vertigo, instabilities when walking on uneven surfaces and in the dark, moving the head rapidly and changing posture in individuals with PN compared to those without PN was observed. Thus, comorbidities such as PN may further intensify complaints of bodily imbalance.

The article by Jáuregui-Renaud et al. (2009) ${ }^{19}$ uses a different methodology than that by Aranda et al. $(2009)^{16}$. However, Jáuregui-Renaud et al. $(2009)^{19}$ describes the main symptoms of PB in individuals with and without DM2 by means of a similar standardized questionnaire. As a result, a higher frequency of PB-related symptoms was observed in subjects with DM2 (Table 1).

The articles included in this review reported the following results: $\mathrm{SAH}$; high $\mathrm{BMI}$; $\mathrm{PN}$; dizziness; vertigo; and postural instability when walking on uneven surfaces or in the dark, looking at moving objects, moving the head rapidly, changing posture, stumbling when walking, and reports of three or more unexplained falls during the year as frequent factors in individuals with $\mathrm{PB}$ and DM2 alterations.

None of the articles included in this study described whether the sample was calculated or randomized, and only one article ${ }^{17}$ described the blinding of the judges. These shortcomings diminish the representativeness and external validity of the studies, making it difficult to understand the veracity of the data presented by the methodological biases. However, the procedures used were described adequately and standardized instruments were used, allowing for the clinical reproducibility of the studies. Thus, the articles were characterized with level of evidence IIb and III, according to ASHA $^{15}$.

It is worth mentioning that changes in PB may have a multifactorial etiology ${ }^{28}$. Therefore, an individual's comprehensiveness when considering the comorbidities presented is extremely important for adequate management of the patient. We emphasize a comprehensive evaluation, considering that there are few studies that present samples with diabetic subjects in addition to the variables mentioned above. Literature shows that clinical-functional and psycho-emotional factors, such as functional capacity, anxiety, and depression $^{29-31}$, are associated with changes in PB in the general population.

Therefore, audiological and otoneurological clinical studies should give special attention to the comorbidities presented by each individual. As these comorbidities are capable of causing changes in the PB and/ or attenuating the process of rehabilitation. This will also aid in the process of therapeutic planning. The treatment and/or stimulation of the altered systems can be the key for the success of the intervention process and, consequently, improvement of the quality of life.

\section{CONCLUSION}

It was found that middle-aged and elderly individuals presented with DM2 and PB changes had a higher frequency of cardiovascular alterations, peripheral neuropathy in the lower limbs, vestibular symptoms, difficulties in tasks/movements in challenging contexts, and falls.

Future studies will be needed to clarify diseases and symptoms associated, so as to accomplish a more preventive, evaluative and interventional design, as DM2 is a potential cause of changes in PB. Robust methodologies must be emphasized as they contribute to the development of an ideal model of care.

\section{REFERENCES}

1. Costa AF, Flor LS, Campos MR, Oliveira AF, Costa MFS, Silva RS et al. Burden of type 2 diabetes mellitus in Brazil. Cad. Saúde Pública. 2017;33(2):e00197915.

2. Sociedade Brasileira de Diabetes. Diretrizes da Sociedade Brasileira de Diabetes (2017-2018). São Paulo: Editora Clannad, 2017. 
3. Lima CLJ, Ferreira TMC, Oliveira PS, Ferreira JDL, Silva EC, Costa MML. Characterization of users at risk of developing diabetes: a cross-sectional study. Rev. Bras. Enferm. 2018;71(supl1):516-23.

4. Flor LS, Campos MR. The prevalence of diabetes mellitus and its associated factors in the Brazilian adult population: evidence from a population-based survey. Rev. Bras. Epidemiol. 2017;20(1):16-29.

5. Lima ACS, Araújo MFM, Freitas RWJF, Zanetti ML, Almeida PC, Damasceno MMC. Fatores de risco para diabetes mellitus tipo 2 em universitários: associação com variáveis sociodemográficas. Rev. Latino-Am. Enfermagem. 2014;22(3):484-90.

6. Ramos RSPS, Marques APO, Ramos VP, Borba AKOT, Aguiar AMA, Leal MCC. Factors associated with diabetes among the elderly receiving care at a specialized gerontology-geriatric outpatient clinic. Rev. Bras. Geriatr. Gerontol. 2017;20(3):364-74.

7. Bittar RSM, Santos MA, Mezzalira R. Glucose metabolism disorders and vestibular manifestations: evaluation through computerized dynamic posturography. Braz J Otorhinolaryngol. 2016;82(4):372-6.

8. Mozetic V, Daou JP, Martimbianco ALC, Riera R. What do Cochrane systematic reviews say about diabetic retinopathy? Cochrane Highlights. 2017;135(1):79-87.

9. Kanadani TC, Cotta BSS, Souza ACCR, Costa APO, Takahashi DM. Evaluation of short-term prognostic factors of ranibizumab in patients with dabetic macular edema. Rev. Bras. Oftalmol. 2018;77(3):137-41.

10. Maronesi CTP, Cecagno-Zanini SC, Oliveira LZ, Bavaresco SS, Leguisamo CP. Physical exercise in patients with diabetic neuropathy: systematic review and meta-analysis of randomized clinical trials. FisioterPesqui. 2016;23(2):216-23.

11. David LZ, Finamor MM, Buss C. Possible hearing implications of diabetes mellitus: a literature review. Rev. CEFAC. 2015;17(6):2018-24.

12. Sociedade Brasileira de Diabetes. Diretrizes da Sociedade Brasileira de Diabetes (2015-2016). São Paulo: A.C. Farmacêutica, 2016.

13. Freeman R, Wieling W, Axelrod FB, Benditt E, Benarroch E, Biaggioni I et al. Consensus statement on the definition of orthostatic hypotension, neurally mediated syncope and the postural tachycardia syndrome. ClinAuton Res. 2011;21(2):69-72.
14. Almeida CPB, Goulart BNG. How to avoid bias in systematic reviews of observational studies. Rev. CEFAC. 2017;19(4):551-5.

15. Mullen R. The state of the evidence: ASHA develops levels of evidence for communication sciences and disorders. 6 de março de 2007. The ASHA Leader, pp. 8-9, 24-25. Disponível em: http://www.asha.org/ Publications/leader/2007/070306/f070306b.htm.

16. Aranda C, Meza A, Rodríguez R, Mantilla MT, Jáuregui-Renaud K. Diabetic polyneuropathy may increasethe handicap relatedto vestibular disease. ArchMed Res. 2009;40(3):180-5.

17. D'Silva LJ, Staecker H, Lin J, Maddux C, Ferraro $J$, Dai $\mathrm{H}$ et al. Otolith dysfunction in persons with both diabetes and benign paroxysmal positional vertigo. Otology\&Neurotology. 2017;38(3):379-85.

18. D'Silva LJ, Whitney SL, Santos M, Dai H, Kluding PM. The impact of diabetes on mobility, balance, and recovery after repositioning maneuvers in individuals with benign paroxysmal positional vertigo. J. diabet. complicat. 2017;31(6):976-82.

19. Jáuregui-Renaud $K$, Sánchez $B$, Olmos Al, González-Barcena D. Neuro-otologic symptoms in patients with type 2 diabetes mellitus. Diabetes Res Clin Pract. 2009;84(3):e4 5-e47.

20. D'Silva LJ, Kluding PM, Whitney SL, Dai H, Santos M. Postural sway in individuals with type 2 diabetes and concurrent benign paroxysmal positional vertigo. Int J Neurosci. 2017;12(12):1065-73.

21. Marchiori LLM, Melo JJ, Possette FLF, Correa AL. Comparison of frequency of vertigo in elderly with and without arterial hypertension. Arq. Int. Otorrinolaringol. 2010;14(4):456-60.

22. Ribeiro WA, Mariano ES, Cirino HP, Teixeira JM, Martins LM, Andrade M. Health education for patients with diabetes mellitus and hypertension in family health strategy. Revista Pró-Univer SUS. 2017;8(2):110-4.

23. Lopes AR, Moreira MD, Trelha CS, Marchiori LLM. Association between complaints of dizziness and hypertension in non-institutionalized elders. Int. Arch. Otorhinolaryngol. 2013;17(2):157-62.

24. Nascimento MM, Pereira LGD, Cordeiro PRN, Araújo LMG. Comparison and agreement of criteria for the BMI classification of physically active elderly women living in the Backlands, semi-arid Region. J Hum Growth Dev. 2017;27(3):342-9.

25. Wannmacher L. Obesidade como fator de risco para morbidade e mortalidade: evidências sobre o 
manejo com medidas não medicamentosas. OPAS/ OMS - Representação Brasil. 2016;1 (7):1-10.

26. Himes CL, Reynolds SL. Effect of obesity on falls, injury, and disability. J AmGeriatr Soc. 2012;60(1):124-9.

27. Hooker SA, MacGregor KL, Funderburk JS, Maisto AS. Body mass index and depressive symptoms in primary care settings: examining the moderating roles of smoking status, alcohol consumption and vigorous exercise. ClinObes. 2014;4(1):21-9.

28. Gazzola JM. Dizziness in the elderly. Rev. Bras. Geriatr. Gerontol. 2018;21(1):5-6.

29. Sousa RF, Gazzola JM, Ganança MM, Paulino CA. Correlation between the body balance and functional capacity from elderly with chronic vestibular disorders. Braz J Otorhinolaryngol. 2011;77(6):791-8.

30. Ferreira LMBM, Jerez-Roig J, Ribeiro KMOBF, Moreira FSM, Lima KC. Association between continuous use drugs and dizziness in institutionalized elderly people. Rev. CEFAC. 2017;19(3):381-6.

31. Borges MGS, Rocha LR, Couto EAB, Mancini PC. Comparison of balance, depression, and cognition in institutionalized and non-institutionalized elderly individuals. Rev. CEFAC. 2013;15(5):1073-9. 